\title{
Macroecology of live-bearing in fishes: latitudinal and depth range comparisons with egg-laying relatives
}

\author{
Nicholas B. Goodwin, Nicholas K. Dulvy and John D. Reynolds
}

\begin{abstract}
Goodwin, N. B., Dulvy, N. K. and Reynolds, J. D. 2005. Macroecology of live-bearing in fishes: latitudinal and depth range comparisons with egg-laying relatives. - Oikos
\end{abstract} 110: $209-218$.

\begin{abstract}
We examine how fishes with contrasting reproductive modes (egg-laying versus live-bearing) differ in geographic range size and distribution. One hypothesis based on dispersal suggests that egg-laying taxa should occupy a wider range of latitudes than live-bearing, whereas the opposite prediction has been derived from the idea that enhanced maternal input and a 'safe harbor' during development will enable livebearers to occupy a wider range of latitudes and depths than egg-layers. Cross-species analysis supports the first hypothesis for teleosts, with egg-layers living in a wider range of latitudes than live-bearers but at lower latitudes, across a narrower depth range and at shallow depth. However, elasmobranchs show the opposite pattern, live-bearers having wider latitudinal ranges. Phylogenetic paired comparisons of sister egg-laying and live-bearing taxa confirm these contrasting patterns between teleosts and elasmobranchs. However, depth range, maximum latitude and depth do not differ with reproductive mode. Latitudinal range size increases with body size among all taxa. However, only teleosts have a positive relationship between body size and maximum latitude, depth and depth range, but this does not differ between reproductive modes. Egg-laying elasmobranchs have low dispersal, but live-bearers have not extended their maximum latitude or depth, despite the benefits of sheltered offspring. The differences in range size between egg-layers and live-bearers and the distinction between teleosts and elasmobranchs is consequence of contrasting mechanisms of dispersal and benefits of maternally buffered transport of developing offspring.
\end{abstract}

N. B. Goodwin and J. D. Reynolds, Centre for Ecology, Evolution and Conservation, School of Biological Sciences, Univ. of East Anglia, Norwich, UK, NR4 7TJ, UK (n.goodwin@uea.ac.uk). _ N. K. Dulvy, Centre for Environment, Fisheries and Aquaculture Science, Pakefield Road, Lowestoft, UK, NR33 OHT.

Life history and ecology are key determinates of geographic range size (Miller 1979, Rohde 1992, Brown 1995, Gaston 1996, 2003, Stevens 1996, Roy et al. 1998). Reproductive mode is one aspect of life history that impacts a species' response to environmental features that determine distribution. For example, in some benthic marine invertebrates latitude and depth vary with the level of maternal investment in larvae (Thorson 1950, Rohde 1985, Emlet 1995) and among north American fishes, parental care tends to be more developed in species with more northerly latitudes and smaller range sizes (Winemiller and Rose 1992). In marine systems, species whose larvae have wide dispersal are expected to have large ranges (Emlet 1995, Gaston 2003).

There are three mechanisms that could yield associations between reproductive mode and distribution among fish species. First, live-bearing species may have an increased likelihood of colonising new habitats compared to egg layers because females can transport offspring across environmental barriers (Wourms and Lombardi 1992). Second, live-bearing may also provide 
a 'safe harbor' for offspring within the female and shield them from environmental extremes, as well as from high rates of predation (Shine 1978, 1989, Shine and Bull 1979, Clutton-Brock 1991, Pope et al. 1994, Qualls and Shine 1998). This hypothesis has also been used to explain the tendency for live-bearing lizards to be found in colder climates than egg-layers, as females are able to use behavioural methods of regulating their body temperatures while carrying developing young (Shine and Bull 1979). Both of these mechanisms predict that live-bearers will occupy larger range sizes than egg-layers. Conversely, the third potential mechanism for linking reproductive mode with range size concerns differences in dispersal of offspring after the female has laid eggs or given birth. Specifically, among most marine egg-laying teleost fishes, dispersal is achieved during broadcast spawning and planktonic development. These species might therefore have larger range sizes due to post-hatching dispersal compared with post-partum dispersal by live-bearers. This hypothesis does not apply to egg-laying elasmobranchs and teleosts that deposit eggs on the substrate (Compagno 1990).

We test these predictions for links between reproductive modes and biogeography using comparative analyses of elasmobranches and teleost fishes. Specifically, we test whether live-bearing species have larger latitudinal and depth ranges than egg-layers, as predicted by maternal transport and environmental buffering, or whether in the case of teleosts, broadcast dispersal has led to larger ranges of egg-layers. We also test whether these links are influenced by relationships between body size and range size (Rapoport 1994, Brown 1995, Gaston 2003). For example, the larger body size of elasmobranchs compared to teleosts (Goodwin et al. 2002) predicts that elasmobranchs will occupy a wider range of latitudes and depths.

\section{Methods}

\section{Phylogeny of live-bearing in fishes}

Two discrete reproductive categories were examined: (1) egg-laying (oviparity), where females spawn eggs with no post-zygotic parental input; and (2) live-bearing (viviparity), where females provide nutrition to the embryo solely through the egg yolk (lecithotrophy), or provide additional nutrient during development, such as via uterine milk, placentation, or oophagy (matrotrophy; Wourms 1981, 1994, Dulvy and Reynolds 1997).

We used the evolutionary transitions to live bearing in fishes that were identified by Goodwin et al. (2002). That study found 11 independent origins of live bearing within teleosts, based on information in Wourms $(1981,1994)$ as well as an extensive literature search. In this study we also included the seahorses and pipefishes (Teleostei: Syngnathidae) and their close relatives the ghost pipefishes (Teleostei: Solenostomidae). In these families the male (Syngnathidae) or female (Solenostomidae) incubates eggs either ventrally or internally in a brood pouch. For elasmobranchs, there is evidence for 9-10 origins of live bearing based on the composite phylogeny by Dulvy and Reynolds (1997). For each of these groups reproductive information was traced onto a phylogeny using MacClade version 3.07 (Maddison and Maddison 1992). We chose the closest pairs of sister clades that differed with respect to reproductive mode. This yielded 21 sister egg-laying and live-bearing comparisons (Appendix 1). The coelacanth, Latimeria chalumnae (Sarcopterygii: Coelacanthidae), could not be included because its egg-laying sister clade comprises the lungfishes (Sarcopterygii: Dipnoi) and tetrapods (Sarcopterygii) that live in freshwater and terrestrial environments. All other known transitions to live-bearing in living fishes are represented.

\section{Latitude, depth and body size}

Data on the latitudes and depths of each species as well as maximum recorded total lengths $(\mathrm{mm})$ were taken from key reviews of taxa, primary scientific papers, aquarist literature and FishBase (Froese and Pauly 2004). Elasmobranch data were also supplemented using Compagno (1984a, b), Quero et al. (1990), Last and Stevens (1994) and Mould (1995). Species maximum recorded total length did not differ significantly from the maximum recorded for the sexes separately. Eschmeyer (1998) was used to confirm the taxonomic validity of species.

We surveyed 1670 species of teleost (750 egg-layers and 920 live-bearers) from 6 orders and 23 families, and 869 species of elasmobranch (343 egg-layers and 526 live-bearers) from 14 orders and 56 families. The total numbers of pairwise comparisons for each variable are as follows, latitude $(n=21)$, depth $(n=20)$ and maximum total length $(\mathrm{n}=21)$ (Appendix 1). The number of species sampled within these paired comparisons depended on the species richness of the group and available data. Range size and distribution measurement error varies among species because these depend upon the extent of sampling throughout each species' range. Species information was included regardless of the sampling effort. Similar percentages of compiled species were represented for each reproductive comparison: maximum length (63\% of live-bearers and $73 \%$ of egg-layers), latitude ( $76 \%$ versus $87 \%$ ) and depth ( $42 \%$ versus $47 \%)$.

\section{Measures of range size}

Species range size and distribution were characterized in five ways using latitude and depth. Latitudinal range: the 
total number of degrees between the northern and southern limits of latitude. Maximum latitude: the maximum latitude from the equator. Latitudinal midpoint: the central latitude between the equator and the maximum latitude represented as a positive value. Depth range: the total number of metres between the minimum and maximum recorded depth. Maximum depth: the maximum depth recorded for a species. Mean depth: when reported, mean or 'typical' depth, otherwise it was the depth at the centre of the depth range.

\section{Comparisons of range size and distribution}

For cross-species analyses (that ignore phylogenetic relationships), species range sizes were compared between egg layers and live bearers using un-paired t-tests (two-tailed). Tests for correlations between body size and range size measures were based on genus values calculated as the arithmetic mean of each genus's member species. In phylogenetically controlled analyses that account for evolutionary history we calculated a nested mean value for each range size measure for each separate egg-laying and live-bearing clade. The nested mean used the taxonomic levels of species, genus and family, based on Eschmeyer (1998) for teleosts, and Compagno (1999) for elasmobranchs (Appendix 1). We based phylogenetic tests on the difference (or contrast) between these nested means for each paired comparison (live-bearing minus egg-laying). Discrete differences in range size between sister egg-laying and live-bearing clades were compared in one-sample t-tests. Data were transformed prior to all analyses; body size and depth data were $\log _{10}+1$ transformed and latitudinal values were expressed as a proportion of the maximum range of values (e.g. maximum latitude $=90$ degrees and maximum latitudinal range $=180$ degrees) and then arcsine square-root transformed. Where appropriate, a Bonferroni test was performed following Rice (1989).

\section{Results}

\section{Range size differences between egg-layers and live- bearers}

Cross-species comparisons of range size show contrasting patterns for teleost and elasmobranch fishes. Teleosts support the prediction, based on post-laying broadcast dispersal, that egg-layers may live across a wider range of latitudes than live-bearers. However, they also support the prediction that egg-layers will be less buffered from environmental extremes, as they live at lower latitudes, across a narrower depth range and at shallower depth than live-bearers (Fig. 1, Table 1A). Elasmobranchs also support the hypotheses based on maternal transport and environmental buffering, as egg-layers occupy a
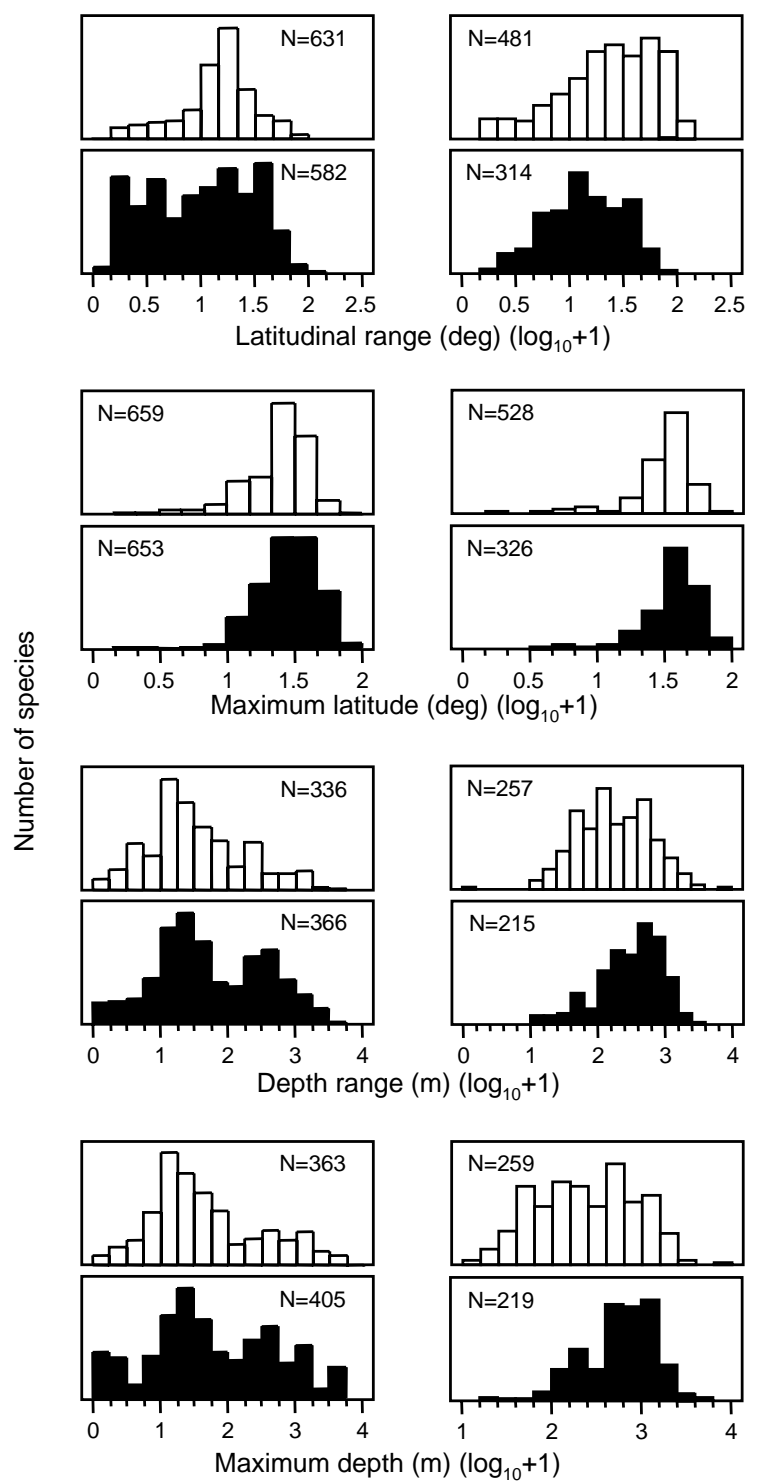

Teleosts

Elasmobranchs

Fig. 1. Cross-species comparisons of geographic range size (both latitude and depth), and limits of distribution for egglaying (open bars) and live-bearing (closed bars) teleosts and elasmobranchs.

narrower range of latitudes than live-bearers (Fig. 1, Table 1A). These taxonomic differences extend to other measures of range size, with egg-laying elasmobranchs living at higher latitudes and across a wider range of depths and at greater depth (Fig. 1, Table 1A).

Thus, of six related tests that are applicable to broadcast dispersal, there was support for only one comparison involving teleosts and two for elasmobranchs (Table 1). Of 10 related tests for the maternal transport and environmental buffering hypothesis, support was found for four (of five) results for teleosts and in one case for elasmobranchs. 
Table 1. Differences in geographic range between egg-laying (EL) and live-bearing (LB) fishes: (A) cross-species (unpaired) and (B) phylogenetic (paired) comparisons. Support for the 'broadcast dispersal (BD)' or the 'maternal transport or environmental buffer $(\mathrm{MT} / \mathrm{B})$ ' hypothesis is shown for each result (NA = not applicable). Degrees of freedom: (A) Teleost: 1186, 1310, 1213, 881, 951; Elasmobranch: 836, 815, 778, 411, 434; (B) Teleost: 11, 11, 11, 8, 8; Elasmobranch: 8, 8, 8, 7, 7.

(A) cross-species

\begin{tabular}{|c|c|c|c|c|c|c|}
\hline & \multirow[t]{2}{*}{ Teleost } & \multicolumn{2}{|c|}{ Hypothesis } & \multirow[t]{2}{*}{ Elasmobranch } & \multicolumn{2}{|c|}{ Hypothesis } \\
\hline & & $\mathrm{BD}$ & $\mathrm{MT} / \mathrm{B}$ & & $\mathrm{BD}$ & $\mathrm{MT} / \mathrm{B}$ \\
\hline Latitudinal range & $\begin{array}{l}\mathrm{EL}>\mathrm{LB} \\
\mathrm{t}=-7.81, \mathrm{P}<0.0001\end{array}$ & $\checkmark$ & $\times$ & $\begin{array}{l}\mathrm{EL}<\mathrm{LB} \\
\mathrm{t}=9.11, \mathrm{P}<0.0001\end{array}$ & $x$ & $\checkmark$ \\
\hline Maximum latitude & $\begin{array}{l}\mathrm{EL}<\mathrm{LB} \\
\mathrm{t}=7.57, \mathrm{P}<0.0001\end{array}$ & $x$ & $\checkmark$ & $\begin{array}{l}\mathrm{EL}>\mathrm{LB} \\
\mathrm{t}=-3.23, \mathrm{P}=0.0013\end{array}$ & $\sqrt{ }$ & $\times$ \\
\hline Latitudinal midpoint & $\begin{array}{l}\mathrm{EL}<\mathrm{LB} \\
\mathrm{t}=7.88, \mathrm{P}<0.0001\end{array}$ & $\times$ & $\checkmark$ & $\begin{array}{l}\mathrm{EL}>\mathrm{LB} \\
\mathrm{t}=-7.96, \mathrm{P}<0.0001\end{array}$ & $\sqrt{ }$ & $x$ \\
\hline Depth range & $\begin{array}{l}\mathrm{EL}<\mathrm{LB} \\
\mathrm{t}=4.40, \mathrm{P}<0.0001\end{array}$ & NA & $\sqrt{ }$ & $\begin{array}{l}\mathrm{EL}>\mathrm{LB} \\
\mathrm{t}=-3.07, \mathrm{P}=0.0023\end{array}$ & NA & $\times$ \\
\hline Maximum depth & $\begin{array}{l}\mathrm{EL}<\mathrm{LB} \\
\mathrm{t}=2.00, \mathrm{P}=0.045\end{array}$ & NA & $\checkmark$ & $\begin{array}{l}\mathrm{EL}>\mathrm{LB} \\
\mathrm{t}=-5.84, \mathrm{P}<0.0001\end{array}$ & NA & $x$ \\
\hline
\end{tabular}

(B) Phylogenetic comparisons

\begin{tabular}{|c|c|c|c|c|c|c|}
\hline & \multirow[t]{2}{*}{ Teleost } & \multicolumn{2}{|c|}{ Hypothesis } & \multirow[t]{2}{*}{ Elasmobranch } & \multicolumn{2}{|c|}{ Hypothesis } \\
\hline & & $\mathrm{BD}$ & $\mathrm{MT} / \mathrm{B}$ & & $\mathrm{BD}$ & $\mathrm{MT} / \mathrm{B}$ \\
\hline Latitudinal range & $\begin{array}{l}\mathrm{EL}>\mathrm{LB} \\
\mathrm{t}=-2.33, \mathrm{P}=0.04\end{array}$ & $\checkmark$ & $\times$ & $\begin{array}{l}\mathrm{EL}<\mathrm{LB} \\
\mathrm{t}=3.81, \mathrm{P}=0.005\end{array}$ & $x$ & $\checkmark$ \\
\hline Maximum latitude & $\begin{array}{l}\mathrm{EL}=\mathrm{LB} \\
\mathrm{t}=0.77, \mathrm{P}=0.46\end{array}$ & $x$ & $\times$ & $\begin{array}{l}\mathrm{EL}=\mathrm{LB} \\
\mathrm{t}=0.71, \mathrm{P}=0.50\end{array}$ & $x$ & $\times$ \\
\hline Latitudinal midpoint & $\begin{array}{l}\mathrm{EL}=\mathrm{LB} \\
\mathrm{t}=1.05, \mathrm{P}=0.32\end{array}$ & $\times$ & $\times$ & $\begin{array}{l}\mathrm{EL}=\mathrm{LB} \\
\mathrm{t}=-0.66, P=0.53\end{array}$ & $\times$ & $x$ \\
\hline Depth range & $\begin{array}{l}\mathrm{EL}=\mathrm{LB} \\
\mathrm{t}=0.54, \mathrm{P}=0.60\end{array}$ & NA & $\times$ & $\begin{array}{l}\mathrm{EL}=\mathrm{LB} \\
\mathrm{t}=0.45, \mathrm{P}=0.67\end{array}$ & NA & $x$ \\
\hline Maximum depth & $\begin{array}{l}\mathrm{EL}=\mathrm{LB} \\
\mathrm{t}=0.44, P=0.67\end{array}$ & NA & $\times$ & $\begin{array}{l}\mathrm{EL}=\mathrm{LB} \\
\mathrm{t}=0.01, \mathrm{P}=0.99\end{array}$ & NA & $x$ \\
\hline
\end{tabular}

Independent paired-comparisons of egg-laying and live-bearing sister taxa confirm the cross-species result that egg-layers occupy a wider latitudinal range than live-bearers among teleosts, and that the opposite is true for elasmobranchs (Table 1B). However, comparisons of maximum latitude, latitudinal midpoint, and depth range and maximum depth suggest that egg-laying and live-bearing fishes have similar range sizes and limits to distribution (Table 1B). Note the greatly reduced sample size in these comparisons. With this sample size caveat in mind, the results can be summarised as follows: of 6 related tests that are applicable to broadcast dispersal, there was support for only one comparison involving teleosts and none in elasmobranches. Of ten tests for the maternal transport and environmental buffering hypothesis, no support was found for teleosts (of five) and there was support for one (of five) tests with elasmobranchs (Table 1).

\section{Body size correlates of range size}

Large-bodied teleost genera have wider latitudinal and depth ranges than smaller-bodied taxa (Fig. 2, Table 2). Elasmobranchs also show a positive body size-latitudinal range size relationship, but the relationship between body size and depth is very weak (Fig. 2, Table 2). The body size-geographic range size relationships do not differ with respect to reproductive mode (Fig. 2, Table 2).

\section{Discussion}

\section{Range and reproductive mode}

The differences in life history between teleosts and elasmobranchs suggest that these taxa have different underlying determinants of distribution (Goodwin et al. 2002). There is mixed support for predictions of hypotheses for links between biogeographic patterns and reproductive modes of fishes. There was strong support among teleosts for the prediction that broadcast dispersal may lead to larger geographic distributions among egg-laying species than for live-bearers. Conversely, elasmobranchs supported the prediction that live-bearers would be more widely distributed than egglayers, through maternal transport and/or buffering of young from environmental extremes during early development. Both of these results were supported by cross-species and phylogenetically-based analyses.

In live-bearers, transport of embryos and environmental buffering by females have been predicted to lead to wider distributions than in egg-laying species 

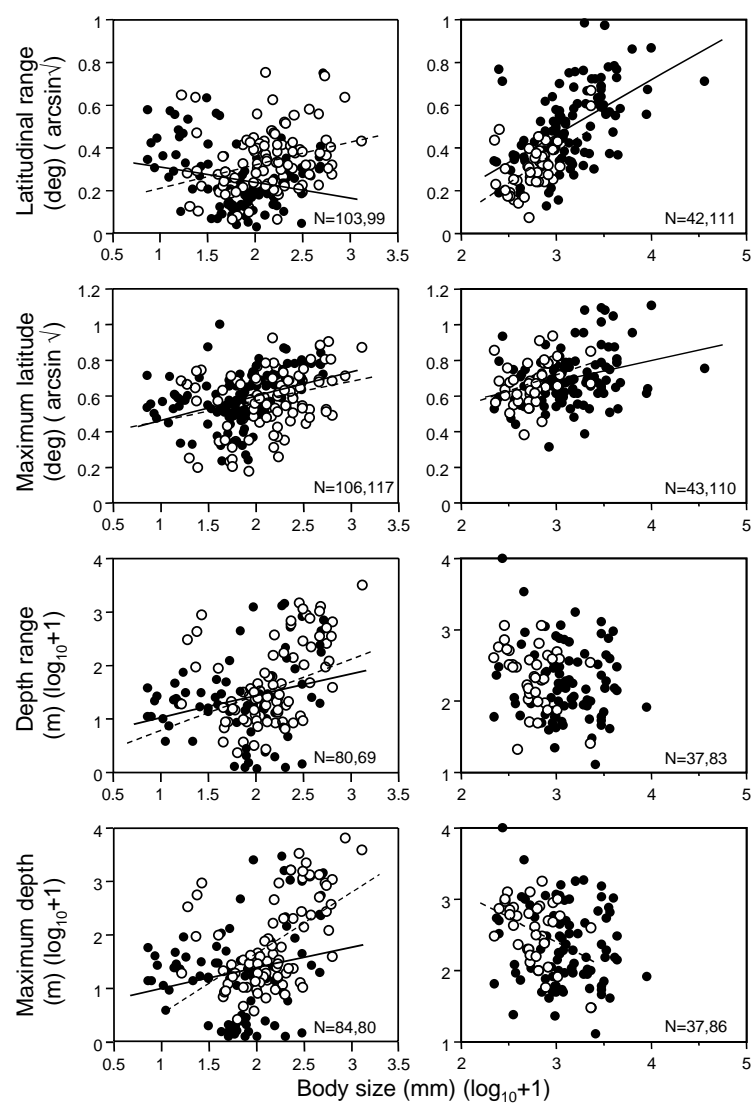

Teleosts

Elasmobranchs

Fig. 2. Relationships between body size and geographic range size (latitude and depth), and limits of distribution for egglaying (open circles) and live-bearing (closed circles) teleosts and elasmobranchs. Each point represents a single genus based on the mean species values. The teleost genus Zoarces, and the elasmobranch genera Galeus and Halaelurus are excluded because they contain both egg-laying and live-bearing species. Only regression lines significant at the 0.05 level are presented, dashed lines $=$ egg-layers, solid lines $=$ live-bearers. Respective sample sizes are shown for egg-layers and live-bearers.

(Wourms 1981, Shine 1989). Alternatively, in teleosts, egg-laying could lead to larger range sizes, due to postspawning dispersal of eggs in water currents (Kinlan and Gaines 2003). Our results support the latter predic- tion for teleosts, and the former prediction for elasmobranchs. However our evidence shows that maximum latitude, depth and depth range do not differ with reproductive mode. Evidence from a wide range of taxa suggests that species with a pelagic or free-swimming development stage disperse widely by drifting on water currents (Kinlan and Gaines 2003); this strategy is typical of marine teleost egg-layers and differs from terrestrial organisms that do not benefit from such passive dispersal mechanisms. In contrast, live-bearing offspring are retained by females and do not have an independent phase of dispersal until birth. This probably influences the pattern that teleost egg-layers are more widely dispersed than live-bearers. This hypothesis, based on broadcast dispersal of eggs, does not apply to elasmobranchs because egg-layers deposit fixed demersal eggs that develop in situ and offspring do not disperse until post-hatching. Adults may also be restricted to regions of suitable spawning substrate on the sea bed, whereas live-bearers could exploit a wider pelagic environment. Furthermore, elasmobranch live-bearers are larger bodied than closely related egg-layers (Goodwin et al. 2002), and larger-bodied organisms tend to have a larger home range size that is correlated with greater dispersal ability and a wider range size (Brown and Maurer 1987, Winemiller and Rose 1992, Brown 1995, Gaston 2003).

The idea that live-bearing females can protect and control their offspring's thermal environment during development was formalized by Tinkle and Gibbons (1977) as the 'cold climate' hypothesis. Guillette et al. (1980) found support for this hypothesis among populations of facultative live-bearing reptiles living in regions with variable temperature regimes that retain offspring when it is cold. There are no recorded incidences of facultative live-bearing in fishes to test the 'safe harbor' hypothesis experimentally. It would be helpful to have more ecological and physiological studies of biotic and abiotic factors that limit reproduction and survival. This information could then be examined in relation to the potential for live-bearing to overcome these constraints and therefore determine limits to distribution.

Table 2. Body size-range size relationships of egg-laying and live-bearing, teleosts and elasmobranchs. Regressions are based on genus averages of transformed species range size measures (Methods). Regression statistics show the gradient of the line, whether it is significantly different from zero and $\mathrm{R}^{2}$ values based on the whole model. See Fig. 2 for illustration of the relationships and sample sizes. $* \mathrm{P}<0.05 ; * * \mathrm{P}<0.01 ; * * * \mathrm{P}<0.001 ; * * * * \mathrm{P}<0.0001$

\begin{tabular}{lcclll}
\hline Range size & Repro mode & \multicolumn{2}{c}{ Teleost } & \multicolumn{2}{c}{ Elasmobranch } \\
\hline Latitudinal range & egg & $0.11, \mathrm{t}=3.1^{* * *}$ & $\mathrm{R}^{2}=0.08$ & $0.29, \mathrm{t}=4.3^{* * * *}$ & $\mathrm{R}^{2}=0.31$ \\
Maximum latitude & live & $-0.09, \mathrm{t}=2.6^{*}$ & $\mathrm{R}^{2}=0.06$ & $0.26, \mathrm{t}=6.6^{* * * *}$ & $\mathrm{R}^{2}=0.29$ \\
& egg & $0.13, \mathrm{t}=3.5^{* * *}$ & $\mathrm{R}^{2}=0.11$ & $0.18, \mathrm{t}=2.4^{*}$ & $\mathrm{R}^{2}=0.12$ \\
Depth range & live & $0.14, \mathrm{t}=4.8^{* * *}$ & $\mathrm{R}^{2}=0.16$ & $0.12, \mathrm{t}=3.4^{* * *}$ & $\mathrm{R}^{2}=0.10$ \\
& egg & $0.89, \mathrm{t}=4.4^{* * * *}$ & $\mathrm{R}^{2}=0.20$ & $-0.55, \mathrm{t}=-1.9^{* *}$ & $\mathrm{R}^{2}=0.10$ \\
Maximum depth & live & $0.38, \mathrm{t}=2.2^{*}$ & $\mathrm{R}^{2}=0.07$ & $-0.21, \mathrm{t}=-1.2$ & $\mathrm{R}^{2}=0.02$ \\
& egg & $1.15, \mathrm{t}=5.59^{* * * *}$ & $\mathrm{R}^{2}=0.28$ & $-0.69, \mathrm{t}=-2.5^{*}$ & $\mathrm{R}^{2}=0.15$ \\
& live & $0.42, \mathrm{t}=2.2^{*}$ & $\mathrm{R}^{2}=0.06$ & $-0.21, \mathrm{t}=-1.2$ & $\mathrm{R}^{2}=0.02$ \\
\hline
\end{tabular}




\section{Range size correlates with body size}

Geographic range size and limits of distribution increase with body size in teleost fishes irrespective of reproductive mode, but the only significant body size relationship that we found among elasmobranchs is with latitudinal range size. These results should be interpreted with caution, because treating genera as independent data points does not address the potential bias caused by shared evolutionary history. However, little more can be done without further phylogenetic information. These results do indicate, however, that direct comparisons of range size between egg-layers and live-bearers are not confounded by body size differences in reproductive mode. A positive body size-range size relationship among teleosts has been shown before in other fish datasets (Roy et al. 1998), but it is not clear why body size is unrelated to depth among elasmobranchs. The wider latitudinal range size of live-bearing elasmobranchs compared to egg-layers is also related to the live-bearers' larger body size. Discussion of the evolution of large body size among live-bearers centres on the large female size required to accommodate their larger offspring (Goodwin et al. 2002). In other taxa, largerbodied individuals usually have large home ranges, which scale up to a larger species total geographic range (Brown and Maurer 1987, Brown 1995, Gaston 2003).

In conclusion, elasmobranchs and teleosts show opposite relationships between range size and reproductive mode, with live-bearing elasmobranchs having wider ranges and live-bearing teleosts having narrower ranges than their egg-laying relatives. We tentatively attribute these differences to contrasting mechanisms of dispersal and benefits of maternally buffered transport of developing offspring.

Acknowledgements - This work was supported by Biotechnology and Biological Sciences Research Council studentships to N.B.G and N.K.D. We are grateful to Anders Berglund and Bill Sutherland for comments on the manuscript.

\section{References}

Anderson, M. E. 1984a. On the anatomy and phylogeny of Zoarcoidei (Teleostei, Perciformes). Unpubl. College of William and Mary, Williamsburg, VA, USA.

Anderson, M. E. 1984b. Zoarcidae, development and relationships. - In: Moser, H. G. (ed.), Ontogeny and systematics of fishes. Am. Soc. Ichthyol. Herpetol., pp. 579-582.

Brown, J. H. 1995. Macroecology. - Chicago Univ. Press.

Brown, J. H. and Maurer, B. A. 1987. Evolution of species assemblages: effects of energetic constraints and species dynamics on the diversification of the North American avifauna. - Am. Nat. 130: 1-17.

Clutton-Brock, T. H. 1991. The evolution of parental care. - Princeton Univ. Press.

Cohen, D. M. and Nielsen, J. G. 1978. Guide to the identification of the genera of the fish order Ophidiiformes with a tentative classification of the order. - NOAA Tech. Rep., NMFS Circular 417. Seattle, WA, US Dept of Commerce.
Collette, B. B. 1995. Tondanichthys kottelati, a new genus and species of freshwater halfbeak (Teleostei, Hemiramphidae) from Sulawesi. - Ichthol. Explor. Fresh. 6: 171-174.

Compagno, L. J. V. 1984a. Sharks of the world. An annotated and illustrated catalogue of shark species known to date. Part1. Hexanchiformes to Lamniformes. - FAO.

Compagno, L. J. V. 1984b. Sharks of the world. An annotated and illustrated catalogue of shark species known to date. Part 2. Carcharhiniformes. - FAO.

Compagno, L. J. V. 1988. Sharks of the order Carcharhiniformes. - Princeton Univ. Press.

Compagno, L. J. V. 1990. Alternative life-history styles of cartilaginous fishes in time and space. - Environ. Biol. Fish. 28: $33-75$.

Compagno, L. J. V. 1999. Checklist of living elasmobranchs. - In: Hamlett, W. C. (ed.), Sharks, skates and rays: the biology of elasmobranch fishes. John Hopkins Univ. Press, pp. $471-498$.

Dingerkus, G. 1983. A revision of the Orectolobiform shark family Hemiscyllidae (Chondrichthyes, Selachii). - Bull. Am. Mus. Nat. Hist. 176: 1-94.

Dingerkus, G. 1986. Interrelationships of Orectolobiform sharks (Chondrichthyes, Selachii). - In: Uyeno, T., Arai, R., Taniuchi, T. et al. (eds), Indo-Pacific fish biology. Ichthyol. Soc. Jap, pp. 227-245.

Dulvy, N. K. and Reynolds, J. D. 1997. Evolutionary transitions among egg-laying, live-bearing and maternal inputs in sharks and rays. - Proc. R. Soc. Lond. B 264: 1309-1315.

Emlet, R. B. 1995. Developmental mode and species geographic range size in regular sea urchins (Echinodermata: Echinoidea). - Evolution 49: 476-489.

Eschmeyer, W. N. (ed.) 1998. Catalog of fishes. - Calif. Acad. Sci.

Froese, R. and Pauly, D. (eds) 2004. FishBase. World wide web electronic publication. www.fishbase.org, version 20 December 2004.

Gaston, K. J. 1996. Species-range-size distributions: patterns, mechanisms and implications. - Trends Ecol. Evol. 11: 197201.

Gaston, K. J. 2003. The structure and dynamics of geographic ranges. - Oxford Univ. Press.

Goodwin, N. B., Dulvy, N. K. and Reynolds, J. D. 2002. Life-history correlates of the evolution of live-bearing in fishes. - Philos. Trans. R. Soc. Lond. B 357: 259-267.

Grudzien, T. A., White, M. M. and Turner, B. J. 1992. Biochemical systematics of the viviparous fish family Goodeidae. - J. Fish Biol. 40: 801-814.

Guillette, L. J., Jr., Jones, R. E., Fitzgerald, K. T. et al. 1980. Evolution of viviparity in the lizard genus Sceloporus. - Herpetologica 36: 201-215.

Ishida, M. 1994. Phylogeny of the suborder Scorpaenoidei (Pisces, Scorpaeniformes). - Nansei Regulatory Fish. Res. Lab. Bull. 27: 112.

Kinlan, B. P. and Gaines, S. D. 2003. Propagule dispersal in marine and terrestrial environments: a community perspective. - Ecology 84: 2007-2020.

Last, P. R. and Stevens, J. D. 1994. Sharks and rays of Australia. - CSIRO.

Maddison, W. P. and Maddison, D. R. 1992. MacClade: analysis of phylogeny and character evolution, version 3.0. - Sinauer.

McEachran, J. D., Dunn, K. A. and Miyake, T. 1996. Interrelationships of the batoid fishes (Chondrichthyes, Batoidea). - In: Stiassny, M. L. J., Parenti, L. R. and Johnson, G. D. (eds), Interrelationships of fishes. Academic Press, pp. 63-84.

Meyer, A. and Lydeard, C. 1993. The evolution of copulatory organs, internal fertilization, placentae and viviparity in killifishes (Cyprinodontiformes) inferred from a DNA phylogeny of the tyrosine kinase gene $X$-src. - Proc. R. Soc. Lond. B 254: 153-162.

Miller, P. J. 1979. Adaptiveness and implications of small size in teleosts. - Symp. Zool. Soc. Lond. 44: 263-306. 
Mould, B. 1995. The nomenclature and distribution of the recent Elasmobranchii. - Univ. of Nottingham (unpubl.) http://ibis.nott.ac.uk/elasmobranch.html.

Nelson, J. S. 1994. Fishes of the World. - Wiley.

Parenti, L. R. 1981. A phylogenetic and biogeographic analysis of cyprinodontiform fishes (Teleostei, Atherinomorpha). - Bull. Am. Mus. Nat. Hist. 168: 335-557.

Pope, J. G., Shepherd, J. G. and Webb, J. 1994. Successful surfriding on size spectra: the secret of survival in the sea. - Philos. Trans. R. Soc. Lond. B 343: 41-49.

Qualls, C. P. and Shine, R. 1998. Lerista bougainvillii, a case study for the evolution of viviparity in reptiles. - J. Evol. Biol. 11: 63-78.

Quero, J. C., Hureau, J. C., Karrer, C. et al. 1990. Check list of the fishes of the eastern tropical Atlantic. - Eur. Ichthyol. Union/UN Educ. Sci. Cult. Org.

Rapoport, E. H. 1994. Remarks on marine and continental biogeography: an aerographical viewpoint. - Philos. Trans. R. Soc. Lond. B 343: 71-78.

Rice, W. R. 1989. Analyzing tables of statistical tests. - Evolution 43: 223-225.

Rohde, K. 1985. Increased viviparity of marine parasites at high latitudes. - Hydrobiologia 127: 197-201.

Rohde, K. 1992. Latitudinal gradients in species diversity: the search for the primary cause. - Oikos 65: 514-527.

Roy, K., Jablonski, D., Valentine, J. W. et al. 1998. Marine latitudinal diversity gradients: tests of causal hypotheses. - Proc. Natl Acad. Sci. USA 95: 3699-3702.

Shine, R. 1978. Propagule size and parental care: the'safe harbor' hypothesis. - J. Theor. Biol. 75: 417-424.

Shine, R. 1989. Ecological influences on the evolution of vertebrate viviparity. - In: Wake, D. B. and Roth G. (eds), Complex organismal functions: integration and evolution in vertebrates. John Wiley and Sons, pp. 263278.

Shine, R. and Bull, J. J. 1979. The evolution of live-bearing in lizards and snakes. - Am. Nat. 113: 905-923.

Slobodyanyuk, S. J., Kirilchik, S. V., Pavlova, M. E. et al. 1995. The evolutionary relationships of two families of cottoid fishes of Lake Baikal (east Siberia) as suggested by analysis of mitochondrial DNA. - J. Mol. Evol. 40: 392-399.

Stepien, C. A., Dixon, M. T. and Hillis, D. M. 1993. Evolutionary relationships of the blennioid fish families Clinidae, Labrisomoidae and Chaenopsidae: congruence between DNA sequence and allozyme data. - Bull. Mar. Sci. 52: $496-515$

Stevens, G. C. 1996. Extending Rapoport's rule to Pacific marine fishes. - J. Biogeogr 23: 149-154.

Streelman, J. T. and Karl, S. A. 1997. Reconstructing labroid evolution with single-copy nuclear DNA. - Proc. R. Soc. Lond. B 264: 1011-1020.

Tinkle, D. W. and Gibbons, J. W. 1977. The distribution and evolution of viviparity in reptiles. - Misc. Publ. Mus. Zool., Univ. Michigan 154: 1-55.

Thorson, G. 1950. Reproductive and larval ecology of marine bottom invertebrates. - Biol. Rev. 25: 1-45.

Winemiller, K. O. and Rose, K. A. 1992. Patterns of life-history diversification in North American fishes: Implications for population regulation. - Can. J. Fish. Aquat. Sci. 49: 21962218.

Wourms, J. P. 1981. Viviparity: the maternal-fetal relationship in fishes. - Am. Zool. 21: 473-515.

Wourms, J. P. 1994. The challenges of piscine viviparity. - Isr. J. Zool. 40: 551-568.

Wourms, J. P. and Lombardi, J. 1992. Reflections on the evolution of piscine viviparity. - Am. Zool. 32: 276-293.

Subject Editor: Esa Ranta

Appendix 1. Summary of live-bearing (LB) and egg-laying (EL) phylogenetic comparisons for teleost fishes (comparisons 1-12) and elasmobranch fishes (comparisons 13-21). Raw data are presented as group means (Methods) for body size and biogeographic traits for each half of the paired comparison. M-marine, F-freshwater, B-brackish.

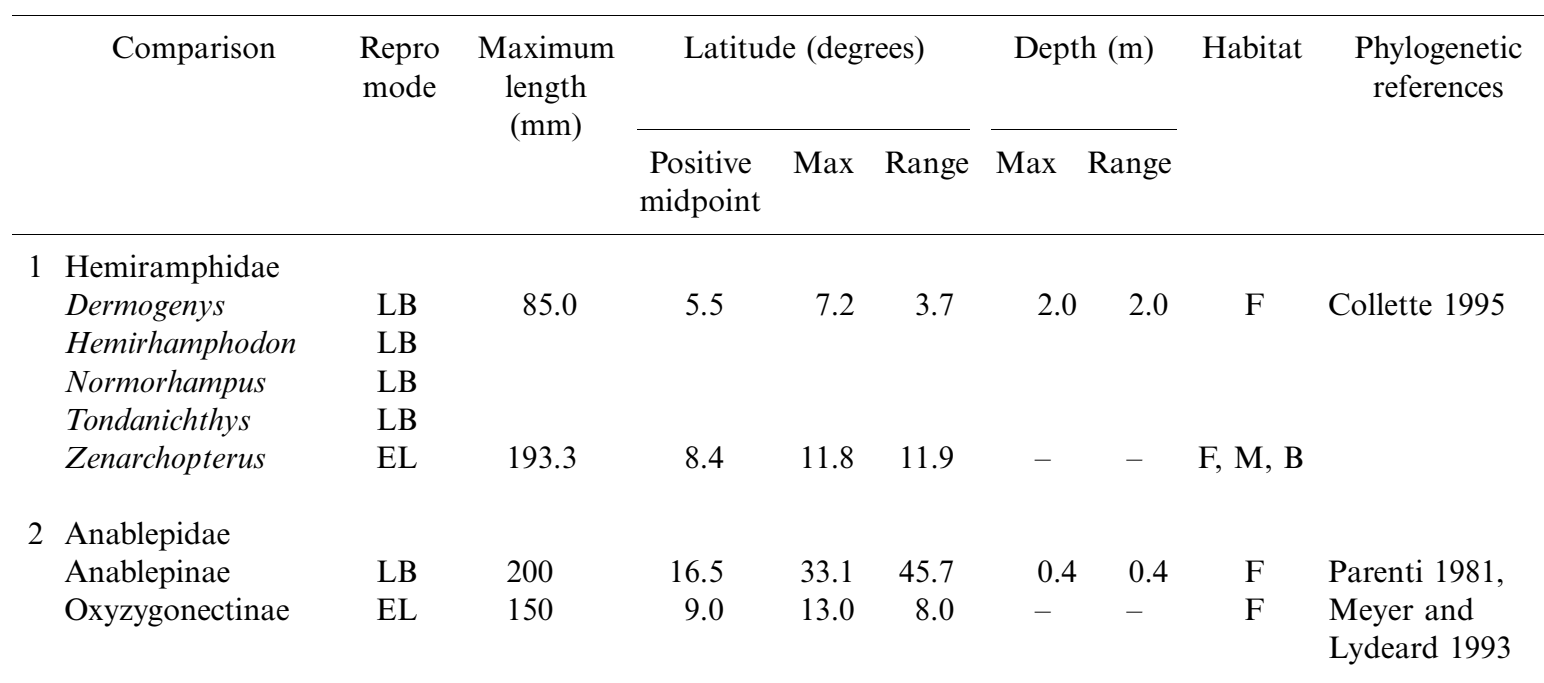


Appendix 1 (Continued)

\begin{tabular}{|c|c|c|c|c|c|c|c|c|c|c|}
\hline & \multirow[t]{2}{*}{ Comparison } & \multirow{2}{*}{$\begin{array}{l}\text { Repro } \\
\text { mode }\end{array}$} & \multirow{2}{*}{$\begin{array}{l}\text { Maximum } \\
\text { length } \\
(\mathrm{mm})\end{array}$} & \multicolumn{3}{|c|}{ Latitude (degrees) } & \multicolumn{2}{|c|}{ Depth (m) } & \multirow[t]{2}{*}{ Habitat } & \multirow{2}{*}{$\begin{array}{l}\text { Phylogenetic } \\
\text { references }\end{array}$} \\
\hline & & & & $\begin{array}{l}\text { Positive } \\
\text { midpoint }\end{array}$ & Max & Range & Max & Range & & \\
\hline \multirow[t]{3}{*}{3} & Goodeidae & & & & & & & & & \\
\hline & Goodeinae & LB & 76.8 & 21.2 & 22.0 & 1.8 & 1.1 & 1.1 & $\mathrm{~F}$ & Parenti 1981, \\
\hline & Empetrichthyinae & EL & 61.0 & 36.7 & 36.9 & 0.5 & 1.8 & 1.5 & $\mathrm{~F}$ & $\begin{array}{l}\text { Grudzien et al. } \\
1992\end{array}$ \\
\hline \multirow[t]{4}{*}{4} & Poeciliidae & & & & & & & & & \\
\hline & Poecilinae & LB & 58.9 & 16.6 & 18.5 & 4.0 & 1.0 & 0.3 & $\mathrm{~F}$ & Parenti 1981, \\
\hline & Aplocheilichthyinae & EL & 56.3 & 5.1 & 7.6 & 6.0 & - & - & $\mathrm{F}$ & $\begin{array}{l}\text { Meyer and } \\
\text { Lydeard } 1993\end{array}$ \\
\hline & Fluviphylacinae & EL & & & & & & & & \\
\hline \multirow[t]{3}{*}{5} & Ophidiiformes & & & & & & & & & \\
\hline & Bythitoidei & LB & 122.9 & 26.8 & 35.3 & 34.8 & 1592.7 & 593.4 & M & $\begin{array}{l}\text { Cohen and } \\
\text { Nielsen } 1978\end{array}$ \\
\hline & Ophidioidei & EL & 346.1 & 21.8 & 33.1 & 29.9 & 831.3 & 373.9 & M & \\
\hline \multirow[t]{3}{*}{6} & Clinidae & & & & & & & & & \\
\hline & $\begin{array}{l}\text { Clinini and } \\
\text { Ophiclinini }\end{array}$ & LB & 112.1 & 34.9 & 27.0 & 6.2 & 20.1 & 18.3 & M & $\begin{array}{l}\text { Stepien et al. } \\
1993\end{array}$ \\
\hline & Myxodini & EL & 231.7 & 31.8 & 40.9 & 18.2 & 35.4 & 33.5 & M & \\
\hline \multirow[t]{4}{*}{7} & Labrisomidae & & & & & & & & & \\
\hline & Starksia & LB & 52.8 & 20.4 & 26.4 & 10.4 & 38.4 & 29.1 & M & $\begin{array}{l}\text { Stepien et al. } \\
1993\end{array}$ \\
\hline & Xenomedea & LB & & & & & & & & \\
\hline & Chaenopsidae & EL & 82.0 & 20.1 & 26.2 & 12.2 & 33.3 & 28.6 & M & \\
\hline & Labrisomidae & EL & & & & & & & & \\
\hline \multirow[t]{2}{*}{8} & Embiotocidae & LB & 244.9 & 34.7 & 42.1 & 14.8 & 61.5 & 59.4 & M & $\begin{array}{l}\text { Streelman and } \\
\text { Karl } 1997\end{array}$ \\
\hline & Pomacentridae & EL & 142.2 & 11.9 & 26.5 & 31.1 & 26.8 & 21.7 & M & \\
\hline \multirow[t]{2}{*}{9} & Zoarces sp. & LB & 610 & 48.0 & 56.3 & 16.5 & 40 & 40 & M & $\begin{array}{l}\text { Anderson } \\
\text { 1984a, 1984b }\end{array}$ \\
\hline & Zoarces americanus & EL & 711 & 46.8 & 56.0 & 18.5 & 240 & 240 & M & \\
\hline \multirow[t]{3}{*}{10} & Sebastidae & & & & & & & & & \\
\hline & Sebastinae & LB & 515.9 & 39.7 & 48.8 & 22.4 & 432.2 & 343.9 & M & Ishida 1994 \\
\hline & Sebastolobinae & EL & 440.0 & 32.4 & 42.5 & 14.5 & 1400.7 & 978.6 & M & \\
\hline \multirow[t]{2}{*}{11} & Comephoridae & LB & 195.0 & 52.0 & 53.0 & 2.0 & 1637.01 & 1487.0 & $\mathrm{~F}$ & $\begin{array}{l}\text { Slobodyanyuk } \\
\text { et al. } 1995\end{array}$ \\
\hline & $\begin{array}{l}\text { Cottidae } \\
\text { Paracottus }\end{array}$ & EL & 144.7 & 52.5 & 58.0 & 11.0 & 50.0 & 49.3 & $\mathrm{~F}$ & \\
\hline \multirow[t]{4}{*}{12} & Syngnathiformes & & & & & & & & & \\
\hline & Solenostomidae & LB & 164.9 & 10.3 & 29.1 & 37.6 & 50.7 & 46.4 & $\mathrm{~F}, \mathrm{M}, \mathrm{B}$ & Nelson 1994 \\
\hline & $\begin{array}{l}\text { Syngnathidae } \\
\text { Aulostomidae }\end{array}$ & $\begin{array}{l}\text { LB } \\
\text { EG }\end{array}$ & 8767 & 124 & 345 & 442 & 2151 & 2009 & M & \\
\hline & & $\mathrm{EG}$ & 876.7 & 12.4 & 34.5 & 44.2 & 215.1 & 200.9 & M & \\
\hline
\end{tabular}


Appendix 1 (Continued)

\begin{tabular}{|c|c|c|c|c|c|c|c|c|}
\hline \multirow[t]{2}{*}{ Comparison } & \multirow[t]{2}{*}{$\begin{array}{l}\text { Repro } \\
\text { mode }\end{array}$} & \multirow{2}{*}{$\begin{array}{l}\text { Maximum } \\
\text { length } \\
(\mathrm{mm})\end{array}$} & \multicolumn{2}{|c|}{ Latitude (degrees) } & \multicolumn{2}{|c|}{ Depth (m) } & \multirow[t]{2}{*}{ Habitat } & \multirow[t]{2}{*}{$\begin{array}{l}\text { Phylogenetic } \\
\text { references }\end{array}$} \\
\hline & & & $\begin{array}{l}\text { Positive } \\
\text { midpoint }\end{array}$ & Max Range & $\operatorname{Max}$ & Range & & \\
\hline
\end{tabular}

$\begin{array}{ll}\text { Centrisidae } & \text { EG } \\ \text { Fistulariidae } & \text { EG }\end{array}$

13 Scyliorhinidae

Galeus arae

Galeus polli

Galeus spp.

EG

EG

14 Halaelurus

Haplobepharus

Holohalaelurus

$\begin{array}{lllllllll}\text { LB } & 380.0 & 17.5 & 31.0 & 40.5 & 726.0 & 480.0 & \text { M } & \\ \text { LB } & & & & & & & & \\ \text { EL } & 482.9 & 33.1 & 40.5 & 14.8 & 810.0 & 568.5 & \text { M } & \\ & & & & & & & & \\ \text { LB } & 461.8 & 23.9 & 48.2 & 18.0 & 495.1 & 234.6 & \text { M } & \text { Compagno } 1988 \\ \text { EL } & 392.5 & 26.0 & 31.6 & 24.7 & 435.0 & 355.0 & \text { M } & \\ \text { EL } & & & & & & & & \end{array}$

15 Proscylliidae

Eridacnis

Ctenacis

Proscyllium

$\begin{array}{lccccccc}\text { LB } & 251.7 & 17.3 & 26.3 & 21.3 & 546.5 & 241.5 & \text { M } \\ \text { EL } & 555.0 & 16.8 & 25.5 & 19.5 & 100.0 & 50.0 & \text { M }\end{array}$

Compagno 1988

16 Pseudotriakidae

EL

Proscylliidae ${ }^{1}$

Ctenacis

Proscyllium

Scyliorhinidae $^{2}$

$\begin{array}{lllllllll}\text { LB } & 2026.0 & 37.0 & 56.5 & 46.5 & 969.5 & 769.5 & \text { M } & \text { Compagno } 1988\end{array}$

17 Leptocharidae

Triakidae

2026.0

EL $\quad 540.0$

EL

EL

Hemigaleidae

LB

1530.5

17.7

31.3

$30.4 \quad 19.3$

$9.3 \quad 353.5 \quad 251.2$

M

Carcharhinidae

LB

Sphrynidae

LB

Proscylliidae ${ }^{1}$

Ctenacis

Proscyllium

EL $\quad 540.0$

21.8

30.4

19.

$\begin{array}{lll}353.5 & 251.2 \quad \mathrm{M}\end{array}$

Scyliorhinidae $^{2}$

EL

18 Orectolobiformes

Rhincodontidae

Stegastomatidae

$$
\text { LB } 36000
$$

EL 2330

21.0

$\begin{array}{llll}- & - \\ 30 & 25\end{array}$

1986

19 Ginglymostomatidae

LB 19090

Rhincodontidae

LB

Hemiscylliidae

EL

764.8

14.6

$25.7 \quad 27.4$

$\begin{array}{ll}66.5 & 97.0\end{array}$

M

20 Brachaeluridae

LB 1871.

22.4

$34.5 \quad 26.5$

$79.2 \quad 79.2$

M

Dingerkus 1983,

Orectolobidae

LB

Parascyllidae

EL

612.5

31.5

35.8

8.6

$182.7 \quad 66$

M

OIKOS 110:2 (2005) 
Appendix 1 (Continued)

\begin{tabular}{|c|c|c|c|c|c|c|c|c|c|c|}
\hline & \multirow[t]{2}{*}{ Comparison } & \multirow{2}{*}{$\begin{array}{l}\text { Repro } \\
\text { mode }\end{array}$} & \multirow{2}{*}{$\begin{array}{l}\text { Maximum } \\
\text { length } \\
(\mathrm{mm})\end{array}$} & \multicolumn{3}{|c|}{ Latitude (degrees) } & \multicolumn{2}{|c|}{ Depth (m) } & \multirow[t]{2}{*}{ Habitat } & \multirow{2}{*}{$\begin{array}{l}\text { Phylogenetic } \\
\text { references }\end{array}$} \\
\hline & & & & $\begin{array}{l}\text { Positive } \\
\text { midpoint }\end{array}$ & Max & Range & Max & Range & & \\
\hline 21 & Rajiformes & & & & & & & & & $\begin{array}{l}\text { McEachran } \\
\text { et al. } 1996\end{array}$ \\
\hline & Myliobatoidea & LB & 2272.3 & 17.2 & 27.5 & 36.8 & 267.9 & 186.4 & M & \\
\hline & Rajidae & EL & 567.5 & 29.8 & 35.6 & 15.1 & 742.1 & 389.3 & $\mathrm{M}$ & \\
\hline
\end{tabular}

${ }^{1}$ excluding Eridacnis.

${ }^{2}$ excluding Galeus area, Galeus polli and Halaelurus. 